\title{
Praktik Kekerasan Simbolik dalam Pemaknaan Perempuan Bekerja Menurut Manhaj Salafi
}

\author{
Prima Ayu Rizqi Mahanani \\ STAIN Kediri \\ prima.ayu99@yahoo.co.id
}

\begin{abstract}
The fact that women working is not a strange thing in the modern era and today's advanced technology. It has become commonplace when we meet the usual work done by men is also done by women. Gender issues in the field of employment are increasingly liquid in the absence of restrictions on the work of men and women's work. The conditions paradox symbolize the concept of work according to the methodology of the Salafis. They clung to the rules, principles, and beliefs that differentiate and limit the type of work between men and women. Convinced that the best place for women is in the private sphere. Where possible women work outside the home must comply with the rules and etiquette that have been determined by the Salafi manhaj. Writing these reflections are trying to dig deeper into the practice of symbolic violence within the meaning of women's work according to the Salafi manhaj. Aiming to know the meaning of work for women Salafi who believes that the best place for women is at home, connected to the concept of symbolic violence. To that used a qualitative approach through the interview method focused on seven informants selected by specific criteria. The results of his research is the practice of symbolic violence does occur in the work according to the methodology of the Salafi discourse. The symbolic violence approved and maintained by the seven women delivered Salafi through language, way of thinking, and how inaction.
\end{abstract}

Keywords: Symbolic Violence, Work, Women, Manhaj Salafi

\begin{abstract}
Abstrak
Fakta perempuan bekerja bukan menjadi hal yang aneh di era modern dan teknologi canggih sekarang ini. Sudah menjadi hal biasa apabila kita jumpai pekerjaan yang biasa dilakukan laki-laki juga dilakukan oleh perempuan. Persoalan gender dalam bidang pekerjaan sudah semakin cair karena tidak adanya pembatasan tentang pekerjaan laki-laki dan pekerjaan perempuan. Kondisi tersebut paradoks dengan pemaknaan konsep bekerja menurut manhaj Salafi. Mereka tetap berpegang teguh pada aturan, prinsip, dan keyakinan yang membedakan dan membatasi jenis pekerjaan antara laki-laki dan perempuan. Meyakini bahwa tempat terbaik bagi perempuan adalah di wilayah privat. Apabila dimungkinkan perempuan bekerja di luar rumah haruslah memenuhi aturan dan adab yang telah ditentukan oleh manhaj Salafi. Tulisan refleksi ini berusaha menggali lebih dalam praktik kekerasan simbolik dalam pemaknaan perempuan bekerja menurut manhaj Salafi. Bertujuan untuk mengetahui tentang makna bekerja bagi perempuan salafi yang berkeyakinan bahwa tempat terbaik bagi perempuan adalah di rumahnya, dihubungkan dengan konsep kekerasan simbolik. Untuk itu digunakan pendekatan kualitatif melalui metode wawancara terfokus kepada tujuh informan yang dipilih melalui kriteria tertentu. Hasil penelitiannya adalah adanya praktik kekerasan simbolik benar terjadi di dalam wacana bekerja menurut manhaj Salafi. Kekerasan simbolis tersebut disetujui dan dilanggengkan oleh ketujuh perempuan Salafi melalui bahasa yang disampaikan, cara berpikirnya, dan cara bertindaknya.
\end{abstract}

Kata kunci: Kekerasan Simbolik, Bekerja, Perempuan, Manhaj Salafi 


\section{Pendahuluan}

Fenomena perempuan bekerja menjadi hal yang semakin biasa di era milenium saat ini. Begitu pula yang terjadi pada masyarakat Indonesia baik di daerah rural maupun urban. Berbagai jenis pekerjaan yang melibatkan kaum hawa, mulai dari usaha mandiri maupun bekerja untuk orang lain atau di sebuah instansi menjadi varian yang bisa dipilih. Beragam motivasi dan kepentingan mengiringi pilihan mereka untuk menghabiskan sebagian waktu menggeluti pekerjaannya.

Di Indonesia sendiri, sepak terjang perempuan di sektor publik terus merangkak naik. Menurut data yang dihimpun Badan Pusat Statistik tahun 2012, pada Agustus 2011 terdapat 45.118.964 perempuan kategori usia produktif yang bekerja di sektor publik. Jumlah ini meningkat pada Februari 2012, yaitu 46.509.689 perempuan kategori usia produktif yang bekerja di sektor publik. Angka ini masih di bawah jumlah laki-laki produktif yang bekerja di sektor publik, yaitu 72.251.521 jiwa pada Agustus 2011 dan 73.907.357 jiwa pada Februari 2013.1

Perempuan patut berbangga karena keinginan mereka untuk bekerja di ranah publik dapat diterima masyarakat luas. Karena jalan perjuangan perempuan mendapatkan "izin boleh bekerja" ini tidak mudah dan berliku. Akses perempuan untuk bekerja tidak semudah laki-laki. Hal ini merupakan imbas dari pelabelan gender terhadap perempuan dan laki-laki sebagai makhluk sosial. Pelabelan ini merupakan konstruksi sosial yang sudah berdiri kokoh sejak lama. Banyak hal-hal yang dilekatkan kepada perempuan dan laki-laki. Misal perempuan diidentikkan dengan penurut dan lemah lembut, sedangkan laki-laki diidentikkan dengan tegas. Padahal hal-hal tersebut bisa dipertukarkan. ${ }^{2}$

Pelabelan ini terus terjadi hingga dewasa. Selama ini, dogma yang berkembang di masyarakat bahwa perempuaan lebih cocok berperan sebagai ibu yang mengemban tugas produksi (menstruasi, mengandung, melahirkan dan menyusui) dan tugas domestik seperti membersihkan rumah, mengurus suami, dan mengurus anak. Sementara, laki-laki dicitrakan sebagai makhluk yang mempunyai kelebihan sehingga dipercayakan berhubungan dengan sektor publik, seperti pencari nafkah ekonomi bagi keluarga. Perempuan bekerja di sektor domestik pada dasarnya bukan bersifat kodrati, sehingga sah-sah saja ketika perempuan memutuskan untuk ikut bekerja di sektor publik. ${ }^{3}$

Menurut Silvia Federich dalam bukunya "Revolution at Point Zero: Housework, Reproduction, and Feminist Struggle", awal mula terjadi penolakkan terhadap pekerjaan rumah (housework) ialah pada era pasca perang Dunia II. Penolakan yang lebih massif terjadi di Italia sekitar tahun 1950-an. Perjuangan

1 Suara 'Aisyiyah Edisi 12 Tahun Ke-90 Desember 2013, h.11

2 Suara 'Aisyiyah Edisi 12 Tahun Ke-90 Desember 2013, h.10

${ }^{3}$ Suara 'Aisyiyah Edisi 12 Tahun Ke-90 Desember 2013, h.11 
kaum perempuan untuk dapat bekerja di sektor publik terus berkembang. Menurut Federich, kerja domestik yang unpaid atau tidak dibayar itulah yang membuat dunia tetap bergerak hingga sekarang. Domestifikasi perempuan pada ranah domestik ini dibungkus dengan indah dengan ilusi tentang cinta pada keluarga. Hal ini membuat perempuan menjadi makhluk yang bergantung pada laki-laki.

Persoalan perempuan bekerja masih menjadi isu yang menarik untuk diperdebatkan. Karena masing-masing individu mempunyai pemahaman yang berbeda dalam memaknai keberadaan perempuan bekerja, terutama di sektor publik. Adanya keyakinan di masyarakat yang mendasarkan pada agama bahwa perempuan yang mengerjakan urusan domestik adalah perempuan mulia, menjadi rujukan bagi yang pro dengan pendapat perempuan lebih baik bekerja di rumah. Cara pikir budaya Jawa yang beranggapan bahwa setinggi apapun pendidikan wanita akhirnya nanti akan tetap berurusan dengan pekerjaan dapur, sumur, dan kasur ikut meneguhkan pendapat tersebut.

Bagi yang kontra atau menyepakati bahwa perempuan tidak identik dengan pekerjaan di dalam rumah tetapi bisa juga bekerja di luar rumah, mengimani bahwa pekerjaan domestik tidak mutlak milik perempuan saja melainkan laki-laki pun bisa melakukan pekerjaan seperti halnya yang dilakukan perempuan. Karena pada dasarnya perempuan juga mempunyai hak dan kewajiban yang sama dengan laki-laki. Perempuan juga mempunyai peluang berkarier sebagaimana laki-laki mendapatkan kesempatan tersebut. Perempuan dan laki-laki sama-sama mendapatkan hak, kesempatan, dan peluang di segala bidang kehidupan kecuali yang kodrati.

Tulisan refleksi ini ingin melihat perempuan yang hidup di era gempitanya kemodernan dan teknologi serba canggih tetapi lebih memilih tinggal di rumah untuk melakukan pekerjaan rumah tangga ataupun kegiatan lainnya. 'Mereka' tidak terpengaruh dengan trend wanita karier yang menjadi impian perempuan modern pada umumnya. 'Mereka' tidak merasa malu untuk tinggal di rumah meskipun mempunyai ijasah pendidikan tinggi setara sarjana atau magister yang laku bila dipakai melamar pekerjaan di sebuah institusi. Mereka yang dimaksudkan dalam tulisan ini adalah perempuan dari manhaj Salafi.

Salafi adalah varian kultural masyarakat muslim yang mengklaim puritan pada ideologi. Mereka ber-Islam dengan menggunakan sarana-sarana yang syar'i dan komitmen kuat dalam mewujudkan tujuan mulia dan agama yang suci, indah lagi sempurna. Mereka selalu berjalan bersama dalil kemana saja dalil itu mengarah. Analisis kritis ini mencoba mengetahui lebih dalam tentang makna bekerja bagi perempuan salafi, yang berkeyakinan bahwa tempat terbaik bagi perempuan adalah di rumahnya, dihubungkan dengan konsep kekerasan simbolik. Asumsi awal saya adalah dimungkinkan terjadinya praktik kekerasan simbolik dalam gagasan bekerja menurut manhaj Salafi. 


\section{Konsep Bekerja menurut Manhaj Salafi}

Penjelasan konsep bekerja menurut manhaj Salafi diambil dari tulisan dr. Adika Mianoki dalam https://muslim.or.id/pahala-melimpah-bagi-muslimahyang-tinggal-di-rumah.html, diakses tanggal 20 Maret 2017. Menurutnya Islam adalah agama yang adil. Allah menciptakan bentuk fisik dan tabiat wanita berbeda dengan pria. Kaum pria diberikan kelebihan oleh Allah Ta'ala baik fisik maupun mental dibandingkan kaum wanita sehingga pantas kaum pria sebagai pemimpin atas kaum wanita. Allah Ta'ala berfirman:

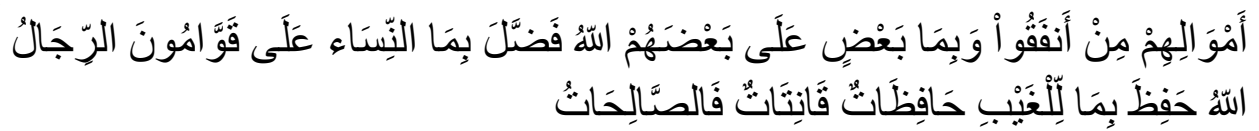

Artinya: "Kaum laki-laki itu adalah pemimpin bagi kaum wanita, oleh karena Allah telah melebihkan sebahagian mereka (laki-laki) atas sebahagian yang lain (wanita), dan karena mereka (laki-laki) telah menafkahkan sebagian dari harta mereka. Sebab itu maka wanita yang saleh, ialah yang ta'at kepada Allah lagi memelihara diri ketika suaminya tidak ada, oleh karena Allah telah memelihara (mereka)" (QS. An Nisa': 34)

Pada asalnya, kewajiban mencari nafkah bagi keluarga merupakan tanggung jawab kaum lelaki. Syaikh Abdul 'Aziz bin Baaz rahimahullah berkata: "Islam menetapkan masing-masing dari suami dan istri memiliki kewajiban yang khusus agar keduanya menjalankan perannya masing-masing sehingga sempurnalah bangunan masyarakat di dalam dan di luar rumah. Suami berkewajiban mencari nafkah dan penghasilan sedangkan istri berkewajiban mendidik anak-anaknya, memberikan kasih sayang, menyusui dan mengasuh mereka, serta tugas-tugas lain yang sesuai baginya seperti mengajar anak-anak perempuan, mengurusi sekolah mereka, dan mengobati mereka serta pekerjaan lain yang khusus bagi kaum wanita. Bila wanita sampai meninggalkan kewajiban dalam rumahnya, berarti ia telah menyia-nyiakan rumah serta para penghuninya. Hal tersebut dapat menyebabkan kerusakan dalam keluarga baik secara hakiki maupun maknawi" (Khatharu Musyarakatil Mar'ah li Rijal fil Maidanil Amal). Dan perlu ditekankan bahwa kewajiban mencari nafkah bukanlah jadi tuntutan bagi wanita namun prialah yang diharuskan demikian (Ath Tholaq:7).

Adika Mianoki mengingatkan agar para wanita muslimah hendaknya jangan tertipu dengan teriakan orang-orang yang menggembar-gemborkan isu kesetaraan gender sehingga timbul rasa minder terhadap wanita-wanita karir dan merasa rendah diri dengan menganggur di rumah. Padahal banyak pekerjaan mulia yang bisa dilakukan di rumah. Di rumah ada suami yang harus dilayani dan ditaati. Ada juga anak-anak yang harus ditarbiyah dengan baik. Ada harta suami yang harus diatur dan dijaga sebaik-baiknya. Ada pekerjaan- 
pekerjaan rumah tangga yang butuh penanganan dan pengaturan. Semua ini pekerjaan yang mulia dan berpahala di sisi Allah Ta'ala. Para wanita muslimah harus ingat bahwa kelak pada hari kiamat mereka akan ditanya tentang amanah tersebut yang dibebankan kepadanya. Namun demikian, jika dalam kondisi tertentu menuntut wanita untuk mencari nafkah, diperbolehkan baginya keluar rumah untuk bekerja, namun harus memperhatikan adab-adab keluar rumah sehingga tetap terjaga kemuliaan serta kesucian harga dirinya.

Sebagian orang juga mendengung-dengungkan bahwa wanita jangan dikungkung dalam rumahnya, karena membiarkan wanita berada di dalam rumah berarti membuang separuh dari potensi sumber daya manusia. Biarkan wanita berperan dalam masyarakatnya, keluar rumah bekerja sama dengan para lelaki untuk membangun negerinya dalam berbagai bidang kehidupan. Harus diketahui bahwa Islam agama yang datang untuk kemaslahatan umat justru memberi pekerjaan yang mulia kepada wanita muslimah. Mereka di antaranya diberi tanggung jawab untuk mendidik anak-anak mereka. Sebuah tanggung jawab yang tidak ringan, sumbangsih yang besar bagi perbaikan umat. Betapa banyak generasi shalih dan shalihah muncul dari tarbiyah yang dilakukan oleh para wanita. Peran orang tua yang dominan dalam mendidik anak berada di pundak para wanita, karena laki laki mempunyai tugas lain yaitu untuk mencari nafkah.

Dengan demikian, pendidikan di rumah merupakan salah satu tanggung jawab yang besar bagi seorang muslimah. Bahkan dengan tetap tinggal di rumahnya, wanita bisa mendapatkan pahala yang banyak dari aktivitas hariannya di dalam rumah yang bisa bernilai pahala. Seperti yang diriwayatkan dari Anas bin Malik, dia mengatakan :

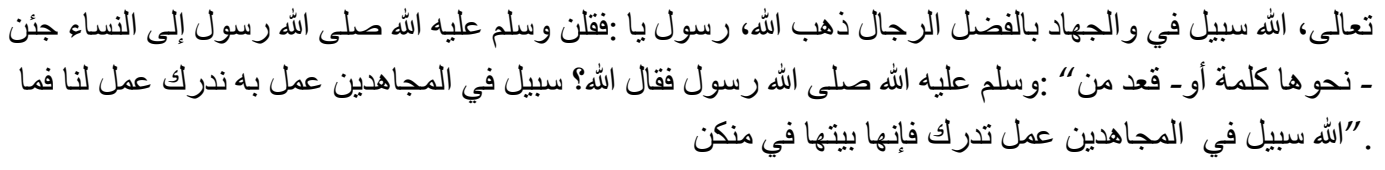

Artinya: "Seorang wanita datang menemui Rasulullah shallallahu 'alaihi wa sallam kemudian berkata: "Wahai Rasulullah, laki-laki memiliki keutamaan dan mereka juga berjihad di jalan Allah. Apakah bagi kami kaum wanita bisa mendapatkan amalan orang yang jihad di jalan Allah? Rasulullah bersabda: "Barangsiapa di antara kalian yang tinggal di rumahnya maka dia mendapatkan pahala mujahid di jalan Allah." (Lihat Tafsir Al Qur'an Al 'Adzim surat Al Ahzab 33).

Dengan tetap tinggal di rumah, bukan berarti wanita tidak bisa ikut andil dalam perbaikan umat. Posisi wanita sebagai sang istri atau ibu rumah tangga memilki arti yang sangat penting bagi perbaikan masyarakatnya. Syaikh Muhammad bin Shalih Al ‘Utsaimin rahimahullah menjelaskan bahwa perbaikan masyarakat dapat dilakukan dengan dua cara: Pertama: Perbaikan secara dhahir. 
Hal ini bisa dilakukan di pasar-pasar, di masjid-masjid dan selainnya dari perkara-perkara yang nampak. Ini didominasi oleh kaum laki-laki karena merekalah yang bisa keluar untuk melakukannya. Kedua: Perbaikan masyarakat yang dilakukan dari dalam rumah. Hal ini dilakukan di dalam rumah dan merupakan tugas kaum wanita. Karena merekalah yang sangat berperan sebagai pengatur dalam rumahnya. Sebagaimana Allah Ta'ala berfirman:

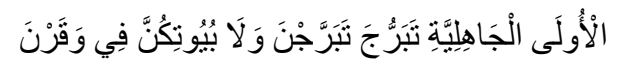

Artinya: "Tetaplah kalian tinggal di dalam rumah-rumah kalian dan janganlah bertabarruj (berpenampilan) sebagaimana penampilannya orangorang jahiliyah yang pertama" (Al Ahzab: 33).

\section{Perempuan Salafi Memaknai Bekerja}

Informasi yang saya kumpulkan dari hasil focus group discussion (FGD) dalam grup Whats App ibu-ibu salafi yang bernama An-Nashihah didapatkan data primer tentang pendapat bahwa fenomena perempuan bekerja di zaman sekarang ini seringkali "dipaksakan" oleh sebagian kalangan. Beberapa di antaranya yang menamakan diri mereka sebagai feminis (yang katanya memperjuangkan hak wanita), berpendapat bahwa wanita harus sejajar dengan laki-laki, wanita tidak boleh dikekang, dan sebagainya. Padahal hal-hal tersebut malah membuat wanita kehilangan kemuliannya.

Ibu-ibu manhaj Salafi mengakui bahwa wanita berbeda dengan laki-laki dalam hal-hal tertentu, sehingga tidak akan bisa seorang wanita bertindak seperti laki-laki, bebas keluar rumah dan eksis di ranah publik. Sebagai contoh, perbedaan laki-laki dan wanita (yang akan berpengaruh dalam pekerjaan yang boleh untuk wanita dan yang tidak) adalah perbedaan fisik. Ini yang pertama. Laki-laki mempunyai fisik yang lebih kuat sehingga mampu menerima tantangan yang keras untuk bekerja di luar rumah, sedangkan wanita dengan kelemahlembutannya diciptakan untuk tetap berada di rumah, mengurusi rumah dan anak-anak mereka. Kedua, perbedaan hormon. Ketiga, perbedaan kondisi fisik dan psikis, diantaranya keadaan wanita yang mudah tersinggung, temperamental, apalagi masa haid. Keempat, perbedaan susunan otak pria dan wanita. Otak laki-laki jauh lebih unggul daripada otak wanita, sehingga lebih cocok bila laki-laki lebih banyak berada di ranah publik (grup Whats App AnNashihah).

Mereka meyakini bahwa Islam adalah agama yang universal. Islam mengatur semua hal, bahkan hal kecil sekalipun, apalagi soal harkat dan martabat wanita. Dalam Islam, wanita sangat dimuliakan. Sebelum datangnya Islam, wanita diperlakukan semena-mena. Pada masa jahiliyah, bayi perempuan dikubur hidup-hidup karena dipandang bahwa wanita hanya akan menyusahkan. Dalam masyarakat Yunani, wanita dipandang sebagai barang yang dapat diperjualbelikan. Dalam masyarakat Hindu, bahkan wanita 
disamakan dengan makhluk jelata yang setingkat dengan kasta hewan. Kemudian Islam datang untuk menempatkan kedudukan wanita pada posisi yang layak, memberikan hak-haknya dengan sempurna tanpa dikurangi sedikitpun. Islam memuliakan kedudukan kaum wanita, baik sebagai ibu, sebagai anak atau saudara perempuan, juga sebagai isteri (grup Whats App AnNashihah).

Mengakui bahwa Islam adalah agama yang sempurna. Tidak mengungkung para wanita dan sama sekali tidak membolehkannya keluar rumah. Ada kalanya wanita dibutuhkan kehadirannya di luar. Atau mungkin mereka membutuhkan sesuatu yang harus didapat dengan cara keluar dari rumahnya. Aturan Islam bila wanita harus keluar rumah, jika wanita mesti keluar rumah untuk bekerja, maka hal-hal berikut yang mesti diperhatikan:

1. Mendapatkan izin dari walinya.

2. Wali adalah kerabat seorang wanita yang mencakup sisi nasabiyah (garis keturunan seperti yang diatur dalam Alquran surat An-Nuur ayat 31).

3. Jika sudah menikah, maka harus mendapat izin dari suamimnya.

4. Berpakaian secara syar'i.

5. Aman dari fitnah.

6. Terjaga agamanya, kehormatannya, serta kesucian dirinya.

7. Menghindari khalwat (berduaan dengan yang bukan mukhrimnya).

8. Ada mahram ketika melakukan safar (bepergian) (HR. Bukhari, Kitab Jazaa-ush shaid Bab Hajjun nisaa', HR. Muslim no. 1341, Kitab Al Hajj Bab Safarul mar-ahma'a mahramin ilal hajj wa ghairihi dari Ibnu Abbas dalam grup Whats App An-Nashihah).

Ada beberapa pekerjaan yang diperbolehkan bagi wanita, selama syaratsyarat di atas terpenuhi, diantaranya adalah: dokter, perawat, bidan, dan pekerjaan di bidang pelayanan medis lainnya. Misalnya bekam, apoteker, pekerja laboratorium. Dokter wanita menangani pasien wanita, anak-anak, dan lelaki dewasa. Untuk menangani lelaki dewasa, maka syaratnya adalah dalam keadaan darurat, misalnya saat peperangan, di mana laki-laki lain sibuk berperang, dan juga ketika dokter spesialis laki-laki tidak ditemui di negeri tersebut (Dalil dari Ar Rubayyi' binti Mu'awwidz, Al Bukhari, Kitab Al-Jihaad was sair Bab Mudaawatyn nisaa' al-jarhaa fil ghazwi, HR. Muslim, Kitab AlJihaad was sair Bab Ghazwun Nisaa' Ma'ar rijaal dalam grup Whats App AnNashihah).

Imam Nawawi menjelaskan hadits tentang kebolehan wanita memberikan pengobatan hanya kepada mahram dan suami mereka saja. Adapun untuk orang lain, pengobatan dilakukan dengan tidak menyentuh kulit, kecuali pada bagian yang dibutuhkan saja. Di bidang ketentaraan dan kepolisian, hanya dibatasi pada pekerjaan yang dikerjakan oleh kaum wanita, seperti memenjarakan wanita, petugas penggeledah wanita, misalnya didaerah perbatasan dan 
bandara. Di bidang pengajaran (ta'lim), dibolehkan bagi wanita mengajar wanita dewasa dan remaja putri. Untuk mengajar kaum pria, boleh apabila diperlukan selama tetap menjaga adab-adab, seperti menggunakan hijab dan menjaga suara (Grup Whats App An-Nashihah).

Menenun dan menjahit tentu ini adalah pekerjaan yang dibolehkan dan sangat sesuai dengan fitrah wanita. Di bidang pertanian, dibolehkan wanita menanam, menyemai benih, membajak tanah, memanen, dan sebagainya. Di bidang perniagaan, dibolehkan wanita untuk melakukan jual beli (hadits Rasulullah). Menyembelih dan memotong daging. Meskipun ada pendapat yang membolehkan pekerjaan ini bagi wanita, namun hakikatnya tidak sesuai dengan tabiat wanita karena membuat tubuhnya tersingkap saat bekerja, seperti lengan dan kaki. Tata rias kecantikan diperbolehkan dengan syarat tidak melakukan hal-hal yang dilarang oleh agama (Grup Whats App An-Nashihah).

Enam informan yang berhasil saya wawancarai secara pribadi melalui media Whats App antara lain: Informan Y berusia 24 tahun, belum menikah, guru di sekolah bermanhaj Salafi, bercadar sejak 2014; Informan A berusia 27 tahun, menikah, berjualan on line, bercadar sejak 2010; Informan I berusia 36 tahun, menikah, wiraswasta percetakan undangan, bercadar sejak 2013; Informan D berusia 23 tahun, menikah, ibu rumah tangga, bercadar sejak 2016, Informan U berusia 37 tahun, menikah, pegawai TU di sekolah bermanhaj Salafi, bercadar sejak 2017; Informan As berusia 33 tahun, menikah, ibu rumah tangga, bercadar sejak 2015. Dari keenam informan tersebut didapatkan penjelasan tentang makna perempuan bekerja antara lain:

Informan Y mengatakan bahwa:

“Kalau untuk bekerja apabila suami masih bisa memenuhi maka tidak usah turut bekerja. Kecuali suaminya memang mendukung untuk bekerja sebab pekerjaannya berhubungan dengan dakwah dan membantu orang lain kayak bidan, guru, guru ngaji, atau dagang yang tidak begitu mengganggu waktu di rumah. Ada yang bidan itupun beliau hanya buka praktik di rumah sebentar aja. Masih lebih banyak waktu untuk rumah. Kalau misal gaji suami untuk kebutuhan pokok pun ndak mencukupi boleh isteri membantu, tapi ya itu pekerjaannya tidak menyita waktu, tidak berkumpul antara laki-laki dan perempuan, mendukung berpakaian sesuai syariat. Saya guru di sekolah bermanhaj salaf juga. Jadi kelas siswa dan siswi dipisah. Kantor ustadz dan ustadzah dipisah".

Informan A menyampaikan bahwa:

"Yang jelas sebaik-baik tempat bagi wanita adalah di rumahnya. Namun apabila dia terpaksa bekerja di luar rumah atau pekerjaannya memang sangat dibutuhkan, misal dokter wanita, guru wanita, maka diperbolehkan dengan syarat bisa menjaga diri. Tidak bercampur baur dengan kaum lelaki, tidak tabarruj/berhias, tidak memakai parfum, menjaga pandangan, tidak safar 
sendirian, dan adab-adab lain. Untuk jualan on line yang saya lakukan itu merupakan wilayah domestik karena cukup duduk manis di rumah".

Informan I menyampaikan bahwa:

“Wanita sebenarnya tidak wajib bekerja di luar rumah, karena tugas di rumah kalau dikerjakan sendiri pasti juga tidak akan ada habisnya, namun apabila suami mengizinkan atau bahkan mendukung tidak mengapa bekerja di luar rumah, asalkan ada batasan-batasannya misalkan tidak ikhtilat (bercampur dengan laki-laki), ada tabir apabila harus berhadapan dengan laki-laki, dan lainlain".

Informan D menyampaikan bahwa:

"Bekerja itu untuk mencari uang sendiri dengan kerja keras sendiri, untuk membantu keluarga atau memenuhi kebutuhan pribadi dan bekerja di luar rumah itu hasil pengabdian kita sama orang lain. Kalo sudah nikah gini, bekerja bukan hal yang harus kita lakukan karena kita punya imam yang mampu menafkahi kita. Memang enak di rumah dan kita malah bisa membuka lapangan pekerjaan sendiri di rumah karena itu sama dengan kerja dan memperkerjakan".

Informan U menyampaikan bahwa:

"Menurutku bekerja dengan tujuan membantu suami dalam rangka menambah nilai ekonomis bagi keluarga dan menambah pengetahuan tentunya yang umum. Tapi yang lebih penting jadi seorang istri dan ibu. Misal istri ingin membantu suami sebenarnya juga gak harus bekerja di luar rumah. Di rumah pun kita usaha juga bisa".

Informan As menyampaikan bahwa:

"Menurut pandanganku bekerja itu ya melakukan sesuatu dengan ikhlas dan senang hati. Ngurus anak dan rumah itu juga bekerja. Harus manut suami, sami'na wa atho'na gak boleh kerja di luar rumah, full ibu rumah tangga".

\section{Praktik Kekerasan Simbolik}

Kekerasan bisa didefinisikan sebagai prinsip tindakan yang mendasarkan diri pada kekuatan untuk memaksa pihak lain tanpa persetujuan. Di dalam kekerasan terkandung unsur dominasi terhadap pihak lain dengan berbagai bentuknya: bisa fisik, verbal, moral, psikologis atau melalui gambar. Penggunaan kekuatan, manipulasi, fitnah, pemberitaan yang tidak benar, pengkondisian yang merugikan, kata-kata yang memojokkan, penghinaan merupakan ungkapan nyata kekerasan. ${ }^{4}$

Kekerasan yang paling sulit diatasi adalah kekerasan simbolis yang beroperasi melalui wacana. Oleh Pierre Bourdieu kekerasan itu disebut

${ }^{4}$ Haryatmoko, Membongkar Rezim Kepastian, Pemikiran Kritis Post-Strukturalis, (Yogyakarta: Kanisius 2016), h. 127 
kekerasan simbolik atau kekerasan yang tak kasat mata. ${ }^{5}$ Disebut simbolis karena dampak yang biasa dilihat dalam kekerasan fisik tidak kelihatan. Tidak terlihat adanya luka, tidak ada traumatis, tidak ada ketakutan atau kegelisahan, bahkan korban tidak merasa telah didominasi atau dimanipulasi.

Makna dan simbol justru sangat berperan untuk penjelasan tentang kekerasan simbolis. Bourdieu melihat mengapa dalam kekerasan simbolis yang dikuasai menerima dan merasa solider dengan yang menguasai dalam konsensus yang sama tentang tatanan yang ada. Jadi, ada semacam persetujuan dari pihak yang dikuasai. Pada dasarnya kekerasan simbolis berlangsung karena ketidaktahuan dan pengakuan dari yang ditindas. Jadi, sebetulnya logika dominasi ini bisa berjalan karena prinsip simbolis yang diketahui dan diterima baik oleh yang menguasai maupun yang dikuasai. Prinsip simbolis itu berupa bahasa, gaya hidup, cara berpikir, cara bertindak, dan kepemilikan yang khas pada kelompok tertentu atas dasar ciri kebutuhan.

Dalam dominasi laki-laki melalui wacana, terlihat cara bagaimana dominasi itu dilakukan dan diderita. Perempuan menjalaninya sebagai kepatuhan seakan wajar. Dampak kekerasan simbolis itu halus, tak terasakan, tak dapat dilihat bahkan oleh korbannya sendiri. Dominasi ini terlaksana melalui cara simbolis berlangsung melalui ketidaktahuan, pengakuan atau perasaan korbannya. Bourdieu mengatakan bahwa yang menentukan makna bahasa lebih sering dari luar linguistik, artinya berkat kepemilikan kapital, terutama kapital simbolik. Cukup mengenaskan bahwa perempuan banyak mengadopsi khasanah bahasa yang kriterianya berasal dari lelaki. Masyarakat tidak sadar bahwa pilihan kata dan penggunaan kalimat tidak pernah netral, tetapi selalu mengandung kepentingan atau nilai. Dengan kata lain, bahasa selalu ideologis.

Penguasaan atas wacana menjadikan dominasi laki-laki seakan-akan sebagai sesuatu yang alamiah dan bisa diterima. Bahkan situasi paling menyiksa dan tak bisa ditolerir bisa tampak wajar. Dalam dominasi laki-laki ini, yang sebetulnya terjadi ialah kekerasan. Kekerasan semacam ini oleh korbannya (kaum perempuan) bahkan tidak dilihat atau tidak dirasakan sebagai kekerasan, tetapi sebagai sesuatu yang alamiah dan wajar.

Dominasi melalui wacana menentukan dalam mendefinisikan pengorganisasian masyarakat dan pembagian kerja. Sering kita mendengar seorang istri mengatakan suaminya setuju bahwa dia meneruskan kariernya. Seakan-akan bagi perempuan, menekuni profesinya itu menjadi mungkin karena belas kasih sang suami. Mengapa justru tidak mengandaikan yang sebaliknya bahwa melalui profesinya itu perempuan mencapai pemenuhan diri. Lelaki itu bisa menjadi suaminya karena menerimanya justru identitasnya termasuk

5 Pierre Bourdieu, Dominasi Maskulin terjemahan oleh Stephanus Aswar Herwinarko, (Yogyakarta: Jalasutra, 2010), h. 7 
profesi itu). Wacana patriarki merupakan kekerasan karena menjebak perempuan dengan menentukan cara melihat, merasakan, berpikir, dan bertindak.

Perempuan juga bisa melakukan dan mencapai keberhasilan yang sama seperti laki-laki, tetapi tujuan-tujuannya, dalam kenyataan, didasarkan pada kepentingan dan nilai-nilai lelaki. Justru ketidakadilannya terletak pada kesan seakan-akan memberi kesempatan yang sama kepada perempuan. Padahal, perempuan berada dalam posisi yang tidak diuntungkan karena seluruh masyarakat secara sistematis lebih memberi keuntungan kepada laki-laki dengan definisinya tentang moral, kerja, kepantasan, jasa. ${ }^{6}$

Perempuan yang tinggal di rumah untuk mengurus anak-anak dan rumah tangga diterima sebagai sesuatu yang sudah semestinya; representasi Tuhan mengacu pada jenis kelamin laki-laki tidak perlu dipertanyakan lagi, dalam Kitab Kejadian dikisahkan bahwa perempuan diciptakan dari tulang rusuk lakilaki harus diterima karena Wahyu, dan sebagainya. Konsepsi antropologis, sosiologis, dan teologis tentang hubungan laki-laki dan perempuan yang tidak menguntungkan perempuan itu tentu saja mempunyai implikasi yang dalam, yaitu kekerasan, maka perlu dibongkar.

Di balik konsepsi tersebut, telah terjadi suatu proses yang bertanggung jawab atas perubahan dari sejarah menjadi seakan-akan sesuatu yang alamiah, dari suatu budaya menjadi seakan-akan sesuatu yang sudah semestinya. Yang alamiah, yang sudah semestinya itu menjadi mitos yang didukung oleh wacana yang dikuasai oleh laki-laki. Mitos itu diterima dan didukung oleh struktur sosio-budaya dan pengorganisasian masyarakat. Pembagian kerja dalam bentuk tugas rumah tangga bagi perempuan dan aktivitas publik untuk laki-laki adalah sebagian dari fakta sejarah, berarti bisa diubah, bukan suatu tatanan alamiah.

Rujukan yang dipakai dasar memaknai konsep bekerja menurut manhaj Salafi yang mengisyaratkan adanya praktik kekerasan simbolik yaitu:

1. Surat An Nisa ayat 34 yang artinya "Kaum laki-laki itu adalah pemimpin bagi kaum wanita, oleh karena Allah telah melebihkan sebahagian mereka (laki-laki) atas sebahagian yang lain (wanita), dan karena mereka (laki-laki) telah menafkahkan sebagian dari harta mereka.

2. Surat Al-Ahzab ayat 33 yang artinya "Tetaplah kalian tinggal di dalam rumah-rumah kalian dan janganlah bertabarruj (berpenampilan) sebagaimana penampilannya orang-orang jahiliyah yang pertama". Yang dimaksud dengan ayat ini adalah hendaknyalah wanita berdiam di rumahnya dan tidak keluar kecuali jika ada kebutuhan. Sehingga jika ada

${ }^{6}$ Haryatmoko, Membongkar Rezim Kepastian, Pemikiran Kritis Post-Strukturalis, (Yogyakarta: Kanisius 2016), h. 158 
pekerjaan bagi wanita yang bisa dikerjakan di rumah, itu tentu lebih layak dan lebih baik.

3. Surat Ath-Tholaq ayat 7 yang menjelaskan tentang penekanan kewajiban mencari nafkah bukanlah jadi tuntutan bagi wanita namun prialah yang diharuskan demikian.

4. Syaikh Abdul 'Aziz bin Baaz rahimahullah mengatakan bahwa Kewajiban mencari nafkah bagi keluarga merupakan tanggung jawab kaum lelaki. Suami berkewajiban mencari nafkah dan penghasilan sedangkan istri berkewajiban mendidik anak-anaknya, memberikan kasih sayang, menyus

5. Adika Mianoki mengingatkan bahwa banyak pekerjaan mulia yang bisa dilakukan di rumah. Di rumah ada suami yang harus dilayani dan ditaati. Ada juga anak-anak yang harus ditarbiyah dengan baik. Ada harta suami yang harus diatur dan dijaga sebaik-baiknya. Ada pekerjaan-pekerjaan rumah tangga yang butuh penanganan dan pengaturan. Semua ini pekerjaan yang mulia dan berpahala di sisi Allah Ta'ala. Para wanita muslim keluar rumah untuk bekerja, namun harus memperhatikan adabadab keluar rumah sehingga tetap terjaga kemuliaan serta kesucian harga dirinya (seperti yang diriwayatkan HR. Bukhari dan HR. Muslim no. 1341, serta dibahas dalam Kitab Jazaa-ush shaid Bab Hajjun nisaa' dan Kitab Al Hajj Bab Safarul mar-ahma'a mahramin ilal hajj wa ghairihi dari Ibnu Abbas).

6. Anas bin Malik mengatakan bahwa peran orang tua yang dominan dalam mendidik anak berada di pundak para wanita, karena laki laki mempunyai tugas lain yaitu untuk mencari nafkah. Dengan demikian, pendidikan di rumah merupakan salah satu tanggung jawab yang besar bagi seorang muslimah. Bahkan dengan tetap tinggal di rumahnya, wanita bisa mendapatkan pahala yang banyak dari aktivitas hariannya di dalam rumah yang bisa bernilai pahala.

7. Syaikh Muhammad bin Shalih Al 'Utsaimin rahimahullah mengatakan bahwa dengan tetap tinggal di rumah, bukan berarti wanita tidak bisa ikut andil dalam perbaikan umat. Posisi wanita sebagai sang istri atau ibu rumah tangga memiliki arti yang sangat penting bagi perbaikan masyarakatnya. Hal ini dilakukan di dalam rumah dan merupakan tugas kaum wanita.

Ketujuh referensi di atas meneguhkan prinsip perempuan Salafi di dalam memahami konsep bekerja. Mereka sangat meyakini bahwa tempat terbaik bagi perempuan adalah di rumah, seperti yang diungkapkan oleh informan A dan As yang memaknai bekerja cukup di dalam rumah saja dan ada larangan dari suami untuk bekerja di luar rumah. Informan Y, I, D, dan U juga menyetujui tempat yang paling mulia bagi perempuan adalah di rumahnya tetapi tidak sekaku infroman A dan As. Mereka memaknai bekerja tidak hanya di dalam rumah tapi 
juga bisa dilakukan di luar rumah dengan izin dan dukungan suami serta diniatkan untuk membantu suami dan ekonomi keluarga.

Ketujuh informan yang saya wawancarai tidak merasa dipaksa oleh fatwafatwa para ulama Salafi dan didominasi oleh suaminya. Mereka memahaminya sebagai bentuk ketaatan dan kepatuhan kepada suami dan sebagai bentuk ketundukkan terhadap kebenaran firman-firman Alloh. Segala yang dilakukan diyakini sepenuhnya sebagai bentuk ibadah kepada Alloh swt. Dapat disimpulkan bahwa praktik kekerasan simbolik benar terjadi di dalam wacana bekerja menurut manhaj Salafi.

Kekerasan simbolis tersebut disetujui dan dilanggengkan oleh ketujuh perempuan Salafi melalui bahasa yang disampaikan, cara berpikirnya, dan cara bertindaknya. Tempat terbaik bagi perempuan adalah di rumah diterima sebagai sesuatu yang sudah semestinya. Mereka menjalaninya sebagai bentuk kepatuhan, ketaatan, dan kesalehan yang seakan alamiah dan wajar, bahwa yang terbaik dan seharusnya memang sudah begitu. Semua yang dilakukan di dalam rumah tidak ada yang sia-sia dan apabila dilakukan dengan ikhlas akan mendapatkan pahala yang besar di sisi Alloh. Bekerja di luar rumah bisa dilakukan setelah mendapat izin dan dukungan dari suami. Hal ini diartikan sebagai bentuk persetujuan, pemberian kesempatan, dan rasa belas kasih sang suami kepada istrinya, bukan karena pemenuhan diri perempuan Salafi itu sendiri untuk berkarya, beraktualisasi, dan berdikari.

Nampak jelas sekali wacana patriarki masih melingkupi cara melihat, merasakan, berpikir dan bertindak dari ketujuh informan ketika memaknai konsep bekerja. Dalam pemaknaan bekerja oleh perempuan Salafi terjadi adopsi khasanah bahasa7 yang kriterianya berasal dari laki-laki. Keputusan bekerja di luar rumah didasarkan pada kepentingan dan nilai laki-laki. Pilihan kata dan penggunaan kalimat dalam konsep bekerja menurut manhaj Salafi dan pemaknaannya oleh ketujuh perempuan Salafi terbukti tidak netral dan mengandung kepentingan atau nilai. Adanya kepentingan untuk mengatur perempuan agar tetap dalam posisi kemuliaan dan kemashlahatan umat serta nilai-nilai kebaikan yang berhadiah pahala di sisi Alloh swt. Dikuatkan juga oleh buku terbitan manhaj Salafi yang berjudul "Pahalamu Lebih Berharga daripada Gajimu" karangan Ustadz Aunur Rofiq ibn Ghufron, Lc. menjelaskan tentang

7 Bahasa seringkali menjadi apparatus hegemoni dari sebuah system kekuasaan melalui dua cara. Pertama, ketika ia tidak memeberi ruang hidup bagi bahasa-bahasa lain (yang plural) karena dianggap sebagai ancaman. Kedua, ketika ia digunakan untuk emnyampaikan informasi (atau versi informasi) yang sesuai dengan kepentingan kekuasaan (Yasraf A. Piliang dalam Fashri (2014:141)). Pandangan tentang kemungkinan bahasa untuk mencerminkan realitas telah memegang kendali selama berabad-abad dan secara konsisten telah berfungsi sebagai pemebnaranatas kekuasaan politik: para tabib, guru, nabi, hakim, pendeta, dokter, dan ilmuwan yelah mengklaim hak-hak atas yang lain berdasarkan superioritas pemahaman merek atentang kebenaran (Harker, 2009:204). 
keutamaan bagi orang yang menghendaki keuntungan di akhirat, menjaga keikhlasan dalam beramal, nasihat tentang jangan keliru memilih niat, dan peringatan bagi pencari dunia belaka. ${ }^{8}$

\section{Interseksi Kekuatan Simbolik dan Tubuh Perempuan}

Kekuatan simbolik adalah suatu bentuk kekuasaan yang diberlakukan atas tubuh secara langsung dan seperti sihir. Kekuasaan itu diberlakukan atas tubuh tanpa menggunakan kekangan fisik apapun. Kita bisa memikirkan keampuhan simbolik pesan religius (misalnya bulla Paus, prediksi, nubuat, dan lain-lain). Keampuhan simbolik itu adalah akibat dari suatu kerja sosialisasi religius yang dilakukan sebelumnya (katekisme, keikutsertaan dalam kultus dan terutama pemberian pengalaman religious yang sangat dini). Untuk konteks masalah dalam tulisan ini, keampuhan kekuatan simbolik disebabkan oleh sosialisasi religius yang disampaikan oleh para ulama Salafi.

Tubuh menjadi sesuatu yang sangat penting, digunakan untuk berargumen dalam teori feminis. Tubuh itulah yang diatur, ada yang mengatur yaitu budaya, agama, negara, institusi yang sifatnya formal/kebiasaankebiasaan, dan lain sebagainya. Tubuh itu tidak pernah netral, digunakan, dibuat, dikonstruksi oleh regime of truth (ekonomi, kapitalis, dan lain-lain). Untuk kasus perempuan Salafi ini, tubuh diatur oleh agama dan dikonstruksi oleh budaya kelompoknya. Seperti yang dikatakan Beauvoir bahwa tubuh mengalami ekspos dan penekanan dari konstruk tertentu yang tidak dapat begitu saja dihindari oleh tubuh. ${ }^{9}$

Tubuh bukan sesuatu yang netral tapi dikontestasikan dalam ruang-ruang kontestasi dalam hal ini di ruang publik. Perempuan Salafi berkontestasi di ruang publik dengan para perempuan di luar kelompoknya dengan tetap memegang teguh ideologi yang dianutnya. Mereka masih tetap bisa berkiprah di sektor publik dengan terus membawa identitas kulturalnya. Mereka masih bisa bekerja sebagai guru, dokter, bidan, dan profesi lainnya dengan tetap mengikuti aturan yang diperintahkan. Tetap memperhatikan adab-adab keluar rumah sehingga tetap terjaga kemuliaan serta kesucian harga dirinya. Tidak ada istilah terkungkung bagi perempuan salafi. Dengan bantuan kemajuan teknologi komunikasi, mereka bisa menembus batas ruang publik dengan tidak perlu keluar dari wilayah domestik.

Manhaj Salafi membantah bahwa apa yang diperjuangkan oleh kaum feminis di dunia dan di Indonesia akan hak perempuan dan kesetaraan gender tidak berlaku bagi kelompok mereka. Tidak ada bahasa tentang ketidakadilan

\footnotetext{
${ }^{8}$ Rofiq Aunur . Pahalamu Lebih Berharga Daripada Gajimu. Kediri: Salman Al-Farisi. 2017), h. $1-7$

9 Prabasmoro, Aquarini Priyatna, Kajian Budaya Feminis: Tubuh, Sastra, dan Budaya Pop, (Yogyakarta: Jalasutra. 2006), h. 60
} 
gender bagi perempuan salafi. Karena antara laki-laki dan perempuan memang sudah ada porsinya masing-masing dan sudah di atur dalam kitab suci Alquran dan kitab-kitab lainnya yang menjadi rujukan kelompok salafi.

Perempuan salafi bersikap demikian berdasarkan dalil-dalil bahwa wanita lebih baik di rumah, menjadi IRT (Ibu Rumah Tangga) karena wanita itu aurat. Banyak pekerjaan mulia yang bisa dilakukan di rumah dan berpahala di sisi Alloh swt. Meyakini kalau nanti di hari kiamat akan ditanya tentang amanah yang dipikulnya. Meyakini apa yang diperintahkan mengandung hikmah dan maslahat bagi dirinya sendiri dan kemaslahatan umat.

Pendapat Betty Friedan (dalam catatan kuliah "Media, Gender, dan Seksualitas) yang mempertanyakan posisi perempuan dalam ruang yang sudah terlembaga secara kultural, sosial, dan politik yang kemudian terkenal pada perjuangan feminisme menjadi hal yang abai dan acuh dalam sudut pandang perempuan Salafi. Bagi perempuan Salafi, tidak menjadi permasalahan besar apabila perempuan tidak pernah dinarasikan karena orientasi mereka adalah ibadah dan mengejar pahala. Kontra sekali dengan pemikiran Betty tentang perempuan yang disembunyikan, perempuan yang tidak bisa menjadi subjek yang dinarasikan di ruang publik dan hanya di ruang privat, absen dari narasi (hidden narration).

Dapat disimpulkan bahwa perempuan Salafi menempatkan tubuh mereka berdasarkan ketetapan yang diyakininya. Menggambarkan fenomena yang paradoksal. Perempuan yang selama ini diasumsikan sebagai suatu hal yang ditanamkan dalam bingkai pemikiran patriarki yang opresif dan heteroseksis tidak menjadi permasalahan bagi perempuan Salafi. Diskriminasi posisi serta peran domestik dan publik yang selama ini didengung-dengungkan oleh kaum feminis tidak mempengaruhi pendirian para perempuan Salafi yang berlindung dalam payung ketaatan. Adanya konstruksi dominan yang menjadi makna bersama (share meaning) tidak membuat perempuan Salafi turut tenggelam didalamnya.

\section{Interseksi Kekerasan Simbolik dan Relasi Kuasa}

Kekerasan simbolik dihubungkan dengan kekuasaan berdasarkan pendapat Bourdieu tentang pemaksaan sistem simbolisme dan makna (misalnya kebudayaan) terhadap kelompok atau kelas sedemikian rupa sehingga hal itu dialami sebagai sesuatu yang sah. Legitimasinya meneguhkan relasi kekuasaan yang menyebabkan pemaksaan tersebut berhasil. Selama dia diterima sebagai sesuatu yang sah, kebudayaan memperkuat dirinya melalui relasi kekuasaan tersebut, memberikan kontribusi kepada reproduksi sistematis mereka. Ini diraih melalui suatu proses salah mengenali (misrecognition): 'suatu proses di mana 
relasi kekuasaan tidak dipersepsikan secara obyektif, namun dalam bentuk yang menjadikan mereka absah di mata pemeluknya'.10

Hidup ini adalah produk kekuasaan yang dinaturalisasikan lewat normalisasi. Tidak meyakini apa yang terjadi pada perempuan Salafi adalah suatu kebetulan begitu saja. Tentunya ada struktur yang mengatur, ada negosiasi juga terhadap struktur, dan juga ada politik identitas.

Setiap kekuasaan pasti ada strukturnya. Dalam hal ini, siapa yang berexercising of power? Menurut Foucault, kekuasaan tidak dimiliki tapi digunakan (exercise). Kekuasaan adalah aneka ragam hubungan kekuatan yang ada di dalam ruang lingkup tempat hubungan-hubungan itu berjalan dan yang mewujudkan organisasinya sendiri. ${ }^{11}$ Tentunya perlu disingkap lagi ada apa dibalik kepatuhan yang dilakukan perempuan Salafi dan ada kepentingan apa dibalik kekuasaan tersebut.

Ada kecurigaan penulis tentang pemaknaan terhadap konsep bekerja oleh perempuan Salafi berhubungan dengan kekuasaan. Karena terdapat posisi subjek yang mempunyai narasi lebih yang menggerakkan perempuan Salafi untuk patuh dan tunduk pada aturan kelompoknya. Merujuk pada pendapat Kathy Davis bahwa ada dua jalur utama untuk memahami relasi gender dan kekuasaan. Pertama, dengan menempatkan gender sebagai konsep sentral dan menggunakannya sebagai analisis atas relasi kuasa. Kedua, kekuasaan ditempatkan sebagai konsep utama dan menjadikannya sebagai titik tolak kritik atas konsep-konsep dalam teori-teori sosial tradisional dengan memahami relasi antar-seks. Kasus tulisan ini lebih tepat apabila menganut pada pendapat pertama. Dalam kehidupan perempuan Salafi dimungkinkan ada subjek kekuasaan yang tergenderkan atau ada bentuk kekuasaan tertentu yang berlaku dalam relasi gender. 12

Narasi yang dominan merupakan aspek penting dalam studi gender karena berhubungan dengan posisi yang berkuasa dan yang mengalami opresi kekuasaan. Dalam hal ini ada cult of domesticity yaitu penempatan perempuan hanya di ruang domestik yang diamini oleh perempuan salafi yang tentunya ada struktur yang mengatur. Struktur yang tepat untuk menjelaskan permasalahan pada perempuan Salafi adalah struktur sosial religius yang memunculkan pandangan "perempuan yang kehidupan religiusnya bermutu" adalah mereka yang menafsirkan kitab suci sebagai sabda Tuhan, tanpa mempersoalkan budaya patriarkhat yang melatarbelakangi penulisan kitab tersebut (Murniati, 2004:19).

${ }^{10}$ Richard Jenkins, Membaca Pikiran Pierre Bourdieu, (Yogyakarta: Kreasi Wacana, 2004), h. 157

11 Fillingham, Lydia Alix, Foucault untuk Pemula, (Yogyakarta: Kanisius. 2001), h. 140

12 Rachmad Hidayat, Ilmu yang Seksis, (Yogyakarta: Jendela, 2004), h. 227 
Pendapat yang saya kutip dari bukunya Murniati ini sesuai dengan pendapat manhaj Salafi mengenai aturan agama Islam tentang wanita bekerja.

Dari data empiris di atas, diketahui bahwa relasi subjek-objek dalam penelitian ini adalah perempuan Salafi sebagai subjek ketika melakukan negosiasi dan apropriasi. Menjadi objek katika masuk dalam pusaran ketetapan dan aturan yang belaku pada kelompoknya. Menurut Gramsci mereka terhegemoni tapi melakukan kreasi-kreasi. Salah satunya dengan memanfaatkan teknologi internet ketika berhubungan dengan ranah publik. Seperti yang dilakukan oleh informan A yang melakukan apropriasi pada konsep bekerja yaitu melakukan pekerjaan jualan on line yang dia kendalikan cukup didalam rumah dan informan I yang membuka usaha percetakan di rumahnya. Dan mereka mengatakan bahwa pekerjaan tersebut adalah wilayah domestik. Sedangkan informan $Y$ dan $U$ bernegosiasi dengan memilih tempat bekerja di wilayah komunitas Salafi. Dapat dikatakan informan A, Y, dan U masih memiliki ruang apropriasi dan negosiasi dalam lingkaran struktur manhaj Salafi.

Terkait politik identitas yang ditampilkan oleh perempuan Salafi tentunya dipengaruhi oleh lingkungan kelompoknya. Diri perempuan Salafi sebagai subjek lebih banyak direpresi dan digantikan oleh diri perempuan sebagai objek kuasa. Konstruksi kelompok Salafi telah menentukan identitas tentang bagaimana ketujuh informan dalam penelitian ini seharusnya berpikir, bersikap, dan berperilaku. Dengan bantuan feminist theology (teologi perempuan), bisa membantu kita untuk mengungkapkan "kepatuhan" yang dilakukan oleh perempuan Salafi dalam memaknai bekerja lebih komprehensif lagi. Teologi perempuan adalah ilmu ketuhanan yang dirumuskan dari sudut pandang perempuan. Sehingga kita bisa memahami bagaimana cara perempuan Salafi berhubungan dengan Tuhannya. 13

Karena di zaman modern seperti sekarang ini tidak banyak perempuan yang mau hanya disibukkan dengan segala seluk beluk pekerjaan rumah tangga, yang itu ternyata diyakini oleh perempuan Salafi sebagai tempat terbaik bagi perempuan. Fakta ini menegaskan bahwa nilai-nilai kelompok Salafi tertanam kuat dalam struktur dan praktik kehidupan sehari-hari, sehingga membuat ketujuh informan perempuan Salafi menerima nilai-nilai tersebut sebagai sesuatu yang objektif dan seharusnya diikuti. Hal ini tentunya tidak bisa dilepaskan dari kepentingan kelompok Salafi untuk tetap pada prinsip memurnikan aqidah dan menebarkan sunnah.

${ }^{13}$ Murniati, A. Nunuk P. Getar Gender: Perempuan Indonesia dalam Perspektif Agama, Budaya, dan Keluarga, (Magelang: Tera, 2004), h. 12 


\section{Penutup}

Ruang publik merupakan ruang yang diperjuangkan oleh perempuan di seluruh belahan dunia ini dengan membawa semangat kesetaraan dan keadilan gender. Konstruksi dominan di zaman modern sekarang ini adalah perempuan bebas untuk berekspresi dan berkreasi di ruang publik seperti yang dilakukan oleh kaum laki-laki. Bagi perempuan masa kini, bekerja di sektor publik merupakan suatu kebutuhan.

Kondisi tersebut paradoks dengan pemaknaan bekerja oleh perempuan Salafi. Perempuan seharusnya tidak menuntut sama dengan laki-laki ketika bekerja di sektor publik. Karena tempat yang paling mulia bagi perempuan adalah di dalam rumah. Mendapat predikat mulia bukan karena persepsi masyarakat tetapi karena ingin meraih kemuliaan di sisi Tuhan.

Memang di dunia ini tidak ada pemaknaan yang universal. Semua orang bebas untuk melakukan pemaknaan yang sifatnya plural. Dalam kasus perempuan Salafi ada agen atau aktor yaitu para ulama Salafi yang dilekati dengan power-power untuk mengarahkan pemaknaan terhadap konsep bekerja, yang bertujuan untuk melanggengkan aturan, prinsip, dan keyakinan yang menjadi identitas manhaj Salafi.

\section{Referensi}

Bourdieu, Pierre. 2010. Dominasi Maskulin terjemahan oleh Stephanus Aswar Herwinarko. Yogyakarta: Jalasutra.

Fashri, Fauzi. 2014. Pierre Bourdieu: Menyingkap Kuasa Simbol. Yogyakarta: Jalasutra.

Fillingham, Lydia Alix. 2001. Foucault untuk Pemula. Yogyakarta: Kanisius.

Jenkins, Richard. 2004. Membaca Pikiran Pierre Bourdieu. Yogyakarta: Kreasi Wacana.

Hidayat, Rachmad. 2004. Ilmu yang Seksis. Yogyakarta: Jendela.

Harker, Richard, Cheelan Mahar dan Chris Wilkes. 2009. Habitus x Modal + Ranah = Praktik, Pengantar Paling Komprehensif Kepada Pemikiran Pierre Bourdieu. Yogyakarta: Jalasutra.

Haryatmoko, 2016. Membongkar Rezim Kepastian, Pemikiran Kritis Post-Strukturalis. Yogyakarta: Kanisius.

---------, 2010. Dominasi penuh Muslihat, Akar Kekerasan dan Diskriminasi. Jakarta: Gramedia Pustaka Utama.

Murniati, A. Nunuk P. 2004. Getar Gender: Perempuan Indonesia dalam Perspektif Agama, Budaya, dan Keluarga. Magelang: Tera.

Prabasmoro, Aquarini Priyatna. 2006. Kajian Budaya Feminis: Tubuh, Sastra, dan Budaya Pop. Yogyakarta: Jalasutra.

Ritzer, George. 2012. Teori Sosiologi, dari Sosiologi Klasik sampai Perkembangan Terakhir Postmodern. Yogyakarta: Pustaka Pelajar.

Rofiq, Aunur Lc. 2017. Pahalamu Lebih Berharga Daripada Gajimu. Kediri: Salman Al-Farisi. 


\section{Sumber Majalah:}

Suara 'Aisyiyah Edisi 12 Tahun Ke-90 Desember 2013.

\section{Sumber Lainnya:}

Materi Kuliah Media, Gender, dan Seksualitas dari Dr. Wening Udasmoro, DEA. M.Hum. 2016. 